\title{
En udenrigspolitisk strategi der nødlandede
}

\section{Martin Marcussen}

Så fik vi en udenrigs- og sikkerhedspolitisk strategi. Det var én af anbefalingerne i den såkaldte granskerrapport, som ambassadør Peter Taksøe-Jensen offentliggjorde tilbage i maj 2016. Det var såmænd en god idé, men den blev desværre dårligt udført. Problemet er, at regeringen glemte at læse resten af granskerrapporten.

I dag har enhver organisation med respekt for sig selv en strategi. Det gælder fodboldklubben, den private virksomhed, kommunerne og enhver anden offentlig organisation. Nogle organisationer har sågar mange strategier, som gerne skulle passe sammen på én eller anden måde. Det gælder eksempelvis universiteterne, og det gælder også udenrigstjenesten.

Strategierne har typisk flere formål. De skal for det første markere, at organisationen har en ledelse, der har styr på sagerne. En ledelse der ikke har en strategi, kan ikke kalde sig en ledelse. Det første, en ny leder ofte gør, er at igangsætte en strategiproces. Det markerer, at vi har med en beslutsom leder at gøre.

Strategier skal for det andet fortælle medarbejderne, hvilke funktioner organisationen har, og hvor den bevæger sig hen. Medarbejderne skulle gerne have en klar fornemmelse af, i hvilken retning organisationen bevæger sig, og hvilken rolle de selv hver især spiller på rejsen mod målet. En organisation står nemlig ikke stille. Den skal per definition bevæge sig ét eller andet sted hen. Nutidens organisationsopfattelse synes at antage, at kun døde organisationer står stille. Hvis organisationen gør, hvad den skal, er det imidlertid heller ikke godt nok. Så begynder lederen at tale om, at organisationen nødvendigvis skal bevæge sig fra det gode til det bedre.

Endelig for det tredje har strategier en vigtig signalfunktion. Omverdenen skal også vide, at den pågældende organisation er vigtig. Den relevante interessent $\mathrm{i}$ omverdenen kan i realiteten være lederens chef, der skal overbevises om, at lederen er en god leder for en god organisation. Omverdenen kan også bestå af andre organisationer. Hvis organisationerne kæmper om de samme ressourcer, indgår strategien som en vigtigt signalværktøj, der er med til at legitimere, at den ene organisa-

Martin Marcussen er professor ved Institut for Statskundskab, Københavns Universitet. Han har bl.a. skrevet Diplomati. Et portræt af den moderne udenrigstjeneste [Hans Reitzels Forlag, 2016] og Diplomati fra bar bund. Hverdagens diplomati på de danske ambassader [DJØfs Forlag, 2017]. 


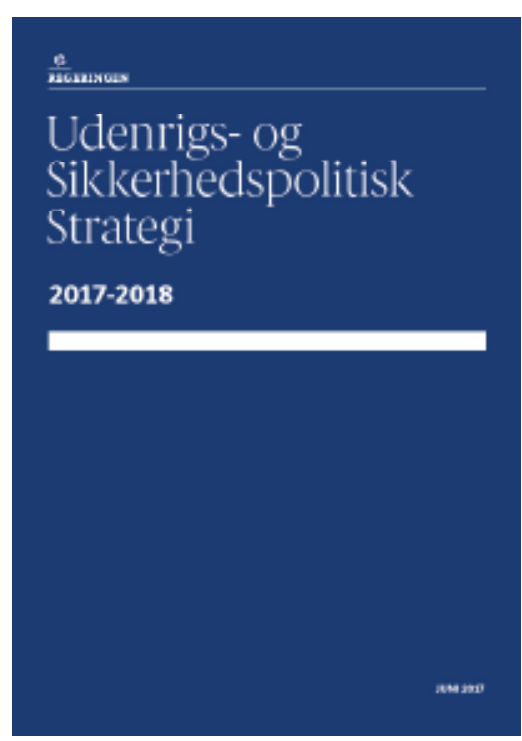

FOTO: Regeringens Udenrigs- og Sikkerhedspolitiske Strategi

tion frem for den anden skal have del i de fælles ressourcer.

\section{De mange strategier}

På trods af disse mange funktioner er der ikke nogen i udenrigstjenesten, der har efterspurgt en udenrigs- og sikkerhedspolitisk strategi. Man har over årene allerede udviklet en stor mængde strategier. Danmark har eksempelvis en udviklingspolitisk strategi. I de senere år er der kommet en ny til, hver gang der er tiltrådt en ny udviklingsminister. Her kan man tale om strategi-overload.

Man har også en strategi for økonomisk diplomati, ligesom man har strategier for en lang række forskellige lande - lige fra Afghanistan og Tyskland til Sydsudan og Bangladesh. Hertil kommer et utal af sektorspecifikke strategier for kultur, ligestilling, FN's fødevareprogram o.s.v, o.s.v. Der er et utal af strategier at vælge mellem.

Også i den daglige styring tænker man strategisk i udenrigstjenesten. Alt er kvantificeret og kategoriseret og sat i kasser og rammer. Det har Moderniseringsstyrelsen sørget for. Med udgangspunkt i vejledningen 'Strategisk styring med resultater i fokus' har alle i udenrigstjenesten faet operationelle pejlemærker for deres daglige virke. Det hele afrapporteres i den standardiserede årsrapport, hvor man kan se, om udenrigstjenesten har indfriet sine målsætninger.

Alligevel skal vi have en ny udenrigsog sikkerhedspolitisk strategi. Tanken er nemlig den, at alle strategierne skal pakkes ind i en 'rammestrategi'. En strategi der er lidt hævet over alle de andre strategier. En slags meta-strategi, som alle andre strategiske tanker og praksisser harmonisk tilpasser sig, og som skal omfatte alle de udenrigs- og sikkerhedspolitiske aktører og institutioner. Strategien over alle strategier.

I tidligere tider spillede regeringsgrundlaget ofte rollen som det overordnede pejlemærke i Danmarks udenrigs- og sik-

\section{Med udgangspunkt i vejled- ningen 'Strategisk styring med resultater i fokus' har alle i udenrigstjenesten fået operationelle pejlemærker for deres daglige virke.}

kerhedspolitik. Det gør det formentlig stadigvæk, men nu er der stukket et ekstra strategisk lag ind mellem regeringsgrundlaget og alle de andre hundredvis af strategier, som det udenrigs- og sikkerhedspolitiske område er præget af.

\section{Hvad står der i en strategi?}

Vi kender efterhånden opskriften på en standardstrategi. De ligner stort set hinanden alle sammen. For det første fremlægges der en analyse af den situation, som organisationen befinder sig i. Der skal med andre 
ord laves en udenrigs- og sikkerhedspolitisk 'swot-analyse.' Det vil sige en vurdering af, hvilke særlige styrker og svagheder den danske udenrigstjeneste har (Strengths and Weaknesses), og hvilke muligheder og begrænsninger et lille land aktuelt har for at gøre sig gældende på den internationale scene (Opportunities and Threaths).

På dette punkt vil det være rimeligt at slå fast, at Danmark har den mindste udenrigstjeneste i Norden, og at den aktuelt står over for større internationale udfordringer, end vi har set længe. Det gælder mod øst (Vladimir Putin), mod vest (Donald Trump), mod nord (Arktis og klimaet), mod syd (flygtninge og immigration), og det gælder ikke mindst hele det institutionelle setup i Bruxelles (Brexit). Der er rigeligt at se til, og også langt mere end den nuværende udenrigspolitiske kapacitet kan rumme.

\section{Ansvarlige politikere må være modige nok til at iden- tificere de områder, hvor den danske indsats reduceres, hvis der med den samme kapacitet foreslås, at ind- satsen intensiveres på en række områder.}

I granskerrapporten var ambassadør Peter Taksøe-Jensen meget eksplicit omkring alle de elementer, der indgår i en sådan swot-analyse. Det er den fremlagte udenrigs- og sikkerhedspolitiske strategi imidlertid ikke. Hele det spørgsmål, der har med 'weaknesses' at gøre, er fuldstændigt udeladt. Vi hører med andre ord ikke noget om, hvorvidt vores udenrigspolitiske kapacitet er gearet til at varetage danske udenrigs- og sikkerhedspolitiske interesser i den nuværende meget tumultariske udenrigspolitiske situation. Hvor Taksøe-Jensen advarer mod de kon- sekvenser som de seneste 15 års løbende nedskæringer i udenrigstjenestens driftsbudget har haft for Danmarks reelle muligheder for at føre udenrigspolitik, så forbigås dette tema fuldstændig i den nye udenrigs- og sikkerhedspolitiske strategi.

For det andet vil vi af en strategi forvente, at der faktisk foretages en prioritering. Hvilke opgaver er langt de væsentligste at beskæftige sig med og ikke mindst: hvilke opgaver skal så nedprioriteres? Det giver sig selv, at hvis der ikke foretages en markant udvidelse af den udenrigspolitiske kapacitet, så er der nogle områder der skal nedprioriteres. Det er præcist dét en strategi også gør: den sender et klart signal om, hvad vi ikke mere skal beskæftige os med.

Det var også lige præcis dét Taksøe-Jensen efterspurgte i sin granskerrapport: et prioriteringsinstrument. Ansvarlige politikere må være modige nok til at identificere de områder, hvor den danske indsats reduceres, hvis der med den samme kapacitet foreslås, at indsatsen intensiveres på en række områder. Politikerne må også stå på mål i offentligheden for deres prioriteringer.

Det sker imidlertid ikke i den fremlagte strategi. Godt nok identificeres en række områder, hvor indsatsen skal opprioriteres (Migration og terrorisme, sikkerhed i nærområdet, Brexit og EU's fremtid, økonomisk og teknologisk diplomati samt Arktis), men der er ingen angivelse af hvilke områder, der så skal nedprioriteres. Der er således ikke tale om et prioriteringsværktøj. Ved pressemødet hvor strategien lanceres, spørger en journalist netop ind til dette punkt i strategien, hvortil udenrigsministeren svarer, at "de mere praktiske ting", det vil sige identifikation af de områder, hvor indsatsen skal reduceres, vil han tage sig af på et se- 
nere tidspunkt: "Selvfølgelig er det sådan, at når man laver en strategiplan som den her, så kan der også ligge nogle fravalg $\mathrm{i}$ det, altså noget, som vi så ikke bruger så meget energi på som hidtil. Men i første omgang fokuserer jeg ind på det, som er topprioriteterne, og så kommer de mere praktiske ting om, hvordan vi gør det, senere" (JyllandsPosten, 14. juni 2017).

For det tredje vil en strategi altid indeholde en sektion om, hvilke instrumenter der kan tages i anvendelse for at nå de beskrevne målsætninger. Typisk vil et land som Danmark satse meget på det internationale samarbejde i organisationer som FN, NATO og EU. Men hvordan vil Danmark arbejde i disse organisationer? Vi har eksempelvis brystet os af, at vi hører til nogle af de smarteste og mest effektive småstater i EU-samarbejdet. Men er der realiteter bag denne selvopfattelse? Betyder det forhold, at vi har reduceret Europakontoret på Asiatisk Plads til en skygge af sig selv; at vi har en af de absolut mindste repræsentationer i Bruxelles målt på antallet af udsendte medarbejdere; og at vi desuden har reduceret antallet af medarbejdere på ambassaderne i Europa - og nedlagt flere af disse - noget for Danmarks performance på den europæiske scene? Det er det store spørgsmål. Det mindste man kan forvente af en strategi er, at man realistisk afmåler indsatsen i forhold til de mål man ønsker at realisere. De medarbejdere, der nu foreslås overført til det europæiske sagområde, er alt for lidt og alt for sent. En dråbe i havet.

Det var Taksøe-Jensen, der med sine anbefalinger igangsatte strategiprocessen, der har holdt medarbejdere i både Udenrigs-, Forsvars- og Statsministeriet beskæftiget i mange måneder. Det paradoksale er imidlertid, at resultatet slet ikke kommer i nærheden af et ligne det strate- giske prioriteringsinstrument, som granskeren efterlyste. Der er i bedste fald tale om en ukontroversiel udenrigspolitisk ønskeliste.

\section{En holdbar strategis kendetegn}

En ting er dog at formulere en strategi. En helt anden ting er at formulere en strategi, der faktisk betyder noget for nogen. En holdbar og effektfuld strategi har også en række kendetegn:

For det første skal den give mening. Man skal umiddelbart kunne forstå, hvorfor strategiens prioriteringer ser ud, som de gør. Det gælder for de områder, man har tænkt sig at opprioritere, såvel som de ting man har tænkt sig at nedprioritere. Man skal ydermere kunne forstå, hvordan de foreslåede udenrigspolitiske instrumenter kan bidrage til at realisere de danske udenrigspolitiske målsætninger. Eksempelvis giver det ikke nogen mening at foreslå, at Danmark skal være meget mere til stede i verden, være meget mere aktiv og endda være toneangivende på en lang række punkter, hvis regeringen ikke også samtidig er parat til at investere i udenrigstjenesten.

På udenrigsministeren må man forstå, at det er man ikke. Adspurgt på det pressemøde, hvor den nye udenrigs- og sikkerhedspolitiske strategi blev lanceret, svarede udenrigsministeren at "Vi har de midler, som vi har til rådighed. Vi har en, synes jeg, meget velfungerende og meget effektiv udenrigstjeneste. Fordi man har et seksspand, er det ikke sikkert, at de løber hurtigere, fordi der kommer en syvende. Det handler om, hvorvidt de er veltrænede, kompetente og dygtige. Jeg er omgivet af fantastisk dygtige folk, som virkelig knokler for at levere varen" (Jyllands-Posten, 14. juni 2017).

Udtalelsen er ikke meningsskabende for 
dem, der følger dansk udenrigspolitik til dagligt, og slet ikke for dem, der til dagligt har sit virke i udenrigstjenesten. Der vises ingen forståelse for eller viden om, at der gennem årene er opstået et misforhold mellem Danmarks erklærede udenrigspolitiske målsætninger på den ene side og de driftsinvesteringer, som skiftende danske regeringer har været parat til at lave for at realisere disse målsætninger på den anden.

En holdbar strategi er for det andet kendetegnet ved, at den har bred opbakning. Det nytter ikke noget, at nogen, der ikke har reel magt til at flytte ting og sager, begynder at udfolde store strategier. Det er et stort arbejde at skabe mening omkring den udenrigspolitiske linje, men det er en endnu større udfordring at skabe accept og opbakning.

Typisk vil man i strategiarbejdet inddrage en lang række forskellige aktører for at tilvejebringe ejerskab omkring strategien. Uden bredt ejerskab får strategien aldrig vinger at flyve med.

Også dette punkt er fremhævet i Taksøe-Jensens granskerrapport. Her fremhæves, at dansk udenrigs- og sikkerhedspolitik i langt højere grad skal tage en bred vifte af aktører fra erhvervslivet, civilsamfundet, de øvrige ministerier, samt universiteter og tænketanke i ed - både i forberedelsesfasen og i implementeringen af udenrigspolitikken. Der tales om at udvide en 'Whole-of-government'-tankegang til en 'Whole-of-society'-tankegang.

Det sker i erkendelsen af, at den udenrigspolitiske beslutningsproces i realiteten er en interessebalancering og altså ikke længere i praksis regeringens prærogativ. Der er i stigende grad behov for at legitimere udenrigspolitikken i det danske samfund og ikke mindst forklare og inddrage samfundet i udenrigspolitikken.

\section{God ide - dårlig udførelse}

Intet af dette er sket i den første fase af strategiprocessen. Strategien som den foreligger, er blevet til i det skjulte. Først er en række kontorer i udenrigstjenesten blevet bedt om at levere input til delelementer, der så er blevet sammenskrevet på højere niveau. Derefter er den sammenskrevne tekst blevet sendt til Statsministeriet, hvor den på et tidspunkt er endt på departementschefens bord. Her er der blevet slettet og føjet til, og dokumentet er sendt retur til Udenrigsministeriet med henblik på videre foranstaltning. Dokumentet er nu offentliggjort og har tiltrukket sig meget begrænset opmærksomhed i medierne. Det er endvidere blevet diskuteret bag lukkede døre i Det Udenrigspolitiske Nævn og skal udgøre grundlaget for en debat i Folketinget.

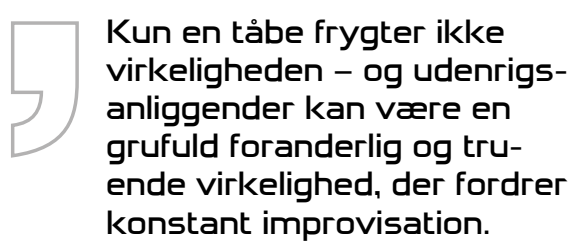

I sammenligning med udarbejdelsen og præsentationen af Peter Taksøe-Jensens granskerrapport kan man næsten ikke forestille sig en mere fremmedartet proces. Til granskeren var knyttet et lille sekretariat og en følgegruppe af forskelligartede interessenter.

I udarbejdelsen brugte granskeren endog meget tid på at lytte til erfaringer fra alle dele af det danske samfund, inklusive Grønland og Færøerne. Der blev endvidere hentet viden hjem fra udlandet. Løbende blev der givet interviews og tekstbidder til de danske medier, og lanceringen af rapporten holdt samtlige nyhedsmedier beskæftigede i ugerne forud såvel som ef- 
ter, at indholdet var kendt. Sjældent er der blevet diskuteret så meget udenrigspolitik i Danmark.

Granskerrapporten bliver ikke glemt, men det er der en stor risiko for, at strategien gør. Med blik for såvel strategiprocessen som strategiens indhold kunne en lederskribent konkludere: "Efter alt at dømme vil strategien snart befinde sig på samme arkivhylde som utallige andre rapporter med gode hensigter. Alle vil vende tilbage til det daglige arbejde, indtil det bliver den næste udenrigsministers tur til med store armbevægelser og indstuderede one-linere at markere sig" (Jyllands-Posten, 15.06.2017).

Endelig skal en holdbar strategi kunne tilpasses situationen. Kun en tåbe frygter ikke virkeligheden - og udenrigsanliggender kan være en grufuld foranderlig og truende virkelighed, der fordrer konstant improvisation. Vi kan jo ikke vide med sikkerhed, om Donald Trumps udenrigspolitik tvinger os til at lægge en grundlæggende transatlantisk søjle om. Vi kan ikke vide med sikkerhed, om Kina vitterlig er klimaets frelser, om EU kommer på fode igen, eller om miljøimmigranter tager retning mod Europa.
Meget kan ske, og meget kommer til at ske. Derfor skal en strategi kunne ændres. Det bliver der sandsynligvis også behov for med den nye strategi. I første omgang er tanken, at den skal gælde for et år. Om udenrigs- og statsministeren til den tid har tænkt sig at fremlægge endnu en $ø$ nskeliste med prioriteringer, kan vi ikke vide.

Det er faktisk slet ikke nemt at lave en strategi i det hele taget. Endnu vanskeligere er det at lave en sikkerheds- og udenrigspolitisk strategi, der giver mening, er bredt accepteret og er tilpas fleksibel på en måde, der gør den relevant også i fremtiden. Men det vanskeligste er nok at samle det politiske mod det kræver at formulere de udenrigspolitiske prioriteter, og vel at mærke tage konsekvenserne af dem.

Alt dette ville regeringen vide, hvis den havde gjort sig den anstrengelse at læse hele granskerrapporten og ikke kun den del, der handler om behovet for en udenrigs- og sikkerhedspolitisk strategi.

En god idé, der desværre blev dårligt udført og ikke mindst dårligt lanceret. 